\title{
Factors Affecting the Transformation of Octacalcium Phosphate to Apatite in vitro
}

\author{
Seiji BAN, Mitsuru MATSUURA, Norihiro ARIMOTO, Jyunko HAYASHIZAKI, \\ Yasuaki ITOH and Jiro HASEGAWA \\ Department of Dental Material Science, School of Dentistry, Aichi-Gakuin University, \\ 1-100, Kusumoto-cho, Chikusa-ku, Nagoya 464, Japan
}

Received May 31, 1993/Accepted October 15, 1993

\begin{abstract}
A fresh octacalcium phosphate $(\mathrm{OCP})$ precipitate without drying and three kinds of dried OCP powders were soaked for 3 weeks in 11 kinds of physiological solutions consisting of different combinations of $\mathrm{Ca}^{2+}, \mathrm{Mg}^{2+}$, $\mathrm{K}^{+}, \mathrm{Na}^{+}, \mathrm{HCO}_{3}{ }^{-}, \mathrm{HPO}_{4}{ }^{2-}, \mathrm{F}^{-}$, albumin, collagen and alkaline phosphatase, in three different $\mathrm{pH}$ values and at three different temperatures. X-ray diffraction study showed that most of the OCP had been transformed to apatite with low crystallinity after soaking in the solutions without $\mathrm{Mg}^{2+}$. The IR absorption spectra revealed that $\mathrm{CO}_{3}$ was incorporated in the apatite formed from OCP in the solution without $\mathrm{Mg}^{2+}$, whereas OCP changed little after soaking in the solution containing $\mathrm{Mg}^{2+}$. These results suggest that the presence of $\mathrm{Mg}^{2+}$ in the solution is one of the most effective means of inhibiting the transformation of OCP to apatite by interrupting the precipitation process of apatite.
\end{abstract}

Key words: Octacalcium phosphate, Apatite, Transformation

\section{INTRODUCTION}

Octacalcium phosphate $\left(\mathrm{Ca}_{8} \mathrm{H}_{2}\left(\mathrm{PO}_{4}\right)_{6} \cdot 5 \mathrm{H}_{2} \mathrm{O}\right.$, hereafter referred to as $\left.\mathrm{OCP}\right)$ has been reported to exist in pathological calcifications and human dental calculi ${ }^{1,2}$. In a neutral $\mathrm{pH}$ region, OCP transforms to calcium-deficient carbonate apatite which is the most thermodynamically stable calcium phosphate phase ${ }^{3,4,5}$. Therefore, OCP has been presumed to be a precursor of biological apatites ; e. g., enamel, dentine, cementum, bones, and phosphatic renal stones ${ }^{6,7,8)}$. On the other hand, a number of authors have concluded on the basis of precipitation and nucleation studies that amorphous tricalcium phosphate (ACP) is formed first and that this then converts to apatite ${ }^{9}$. More recently, it is generally accepted that, in neutral $\mathrm{pH}$ regions, ACP is precipitated first and subsequently OCP is initially nucleated on the surface of the ACP particles and then OCP converts to apatite ${ }^{10}$. Thus, studying this mechanism under a wide variety of experimental conditions should give some more detail in explanation about the formation of biological apatite.

We developed a new preparation method for a quick preparation of a large amount of OCP by reactions of dicalcium phosphate dihydrate $\left(\mathrm{CaHPO}_{4} \cdot 2 \mathrm{H}_{2} \mathrm{O}\right.$, hereafter referred to as DCPD) and calcium carbonate $\left(\mathrm{CaCO}_{3}\right)^{11)}$. In our previous study ${ }^{12)}$, the transformation of the OCP synthesized by this method was investigated in vivo and in vitro. It was found that the OCP completely transformed to apatite within 3 weeks in mouse thigh muscle pouches and in $1 \% \mathrm{NaCl}$ solution, whereas little change was observed in a simulated body fluid. It was concluded that magnesium had a great influence on the rate of transformation to apatite in 
vitro, as reported by many investigators, and physiological reaction to OCP also had a significant effect in vivo. LeGeros et al..$^{3,13)}$ demonstrated that the transformation of OCP to apatite is inhibited by $\mathrm{Mg}^{2+}$, citrate or $\mathrm{P}_{2} \mathrm{O}_{7}{ }^{4-}$, and facilitated by $\mathrm{F}^{-}, \mathrm{CO}_{3}{ }^{2-}, \mathrm{HPO}_{4}{ }^{2-}$ or $\mathrm{Ca}^{2+}$ ions. Many other investigators ${ }^{8,14-17)}$ have also confirmed the effect of $\mathrm{Mg}^{2+}$ ions on the transformation of OCP to apatite. However, it is still not clarified which ions inhibit and which stimulate the transformation of OCP. For instance, Eidelman et al. ${ }^{4)}$ reported that $\mathrm{CO}_{2}$ slowed the transition of OCP to apatite. There are also some reports about the effect of proteins on the transformation of calcium phosphates. Sauer and Wuthier ${ }^{10)}$ demonstrated that an early driving force of mineral ion uptake is the binding of $\mathrm{Ca}^{2+}$ to proteins and lipids within the vesicle lumen. Wuthier and Eanes ${ }^{18)}$ suggested that lipids may play a role in the control of normal mineralization in vivo. Blumenthal et al. ${ }^{19)}$ reported that type I collagen exerts a considerable inhibitory effect on apatite proliferation. Doi et al..$^{20}$ suggested that the immobilized dentin phosphoprotein could work as a nucleating substrate for the OCP phase in solutions where calcium and phosphate concentrations are sufficiently higher than equilibrium saturation levels for the OCP phase. However, there are still a lot of factors which have to be clarified in this phenomenon; e. g., drying after precipitation, organic substances, and their interaction in the solution, etc.

The present work, therefore, was undertaken to study the effect of the drying condition of OCP, composition of the soaking solution, $\mathrm{pH}$ and temperature of the solution on the transformation of OCP to apatite in vitro, and the factors with the greatest effect on transformation between in vivo and in vitro are compared.

\section{MATERIALS AND METHODS}

OCP was chemically synthesized from a suspension of DCPD and $\mathrm{CaCO}_{3}$. A suspension was prepared containing $0.02 \mathrm{~mol}$ of $\mathrm{DCPD}$ and $0.0067 \mathrm{~mol}$ of $\mathrm{CaCO}_{3}$ in a vial containing $200 \mathrm{ml}$ of distilled water. The suspension was incubated at $60^{\circ} \mathrm{C}$, and stirred by a Teflon-coated magnetic stirrer. The precipitate was filtered after $24 \mathrm{~h}$. Details of the preparation method are the same as those described previously ${ }^{11}$. To investigate the effect of the dry condition, four kinds of specimens were used for the soaking test: (1) Fresh precipitate without drying, (2) powder dried at room temperature for 10 days in air, (3) powder dried at $60^{\circ} \mathrm{C}$ for $6 \mathrm{~h}$ in air, and (4) lyophilized powder prefrozen at $-80^{\circ} \mathrm{C}$ and dried in a $5 \mu \mathrm{mHg}$ vacuum.

These four kinds of OCP specimens, $100 \mathrm{mg}$ each, were stored in vials containing $50 \mathrm{ml}$ of test solution. To investigate the effect of the composition of the immersed solution, all OCP powders were soaked in 11 kinds of test solutions for 3 weeks. Table 1 shows the ion concentrations of the test solutions used in this study. These solutions were prepared by dissolving given amounts of reagent-grade chemicals of $\mathrm{NaCl}, \mathrm{NaHCO}, \mathrm{KCl}, \mathrm{K}_{2} \mathrm{HPO}_{4}$, $\mathrm{MgCl}_{2} \cdot 6 \mathrm{H}_{2} \mathrm{O}$, and $\mathrm{CaCl}_{2} \cdot 2 \mathrm{H}_{2} \mathrm{O}$ into distilled water. The solutions were buffered at a $\mathrm{pH}$ of 7.2 with $50 \mathrm{mM}$ trishydroxyaminomethane $\left[\left(\mathrm{CH}_{2} \mathrm{OH}\right)_{3} \mathrm{CNH}_{2}\right]$ and an adequate amount of hydrochloric acid $(\mathrm{HCl})$. The simulated body fluid $(\mathrm{SBF})$ in which ion concentrations were similar to those of human blood plasma ${ }^{21}$ is referred to as solution $A$. Solution $B$ consists of only $\mathrm{Na}^{+}$and $\mathrm{Cl}^{-}$ions ; $i$. e., buffered saline solution. Solution $C$ contains no $\mathrm{Ca}^{2+}$ ion ; solution $D$, no $\mathrm{Mg}^{2+}$ ion ; solution $E$, neither $\mathrm{K}^{+}$ion nor $\mathrm{HPO}_{4}{ }^{2-}$ ions ; solution $F$, no $\mathrm{HCO}_{3}{ }^{-}$ 
Table 1 Ion concentration (mM) of test solutions used

\begin{tabular}{|c|c|c|c|c|c|c|c|c|c|}
\hline No & Code & $\mathrm{Na}^{+}$ & $\mathrm{K}^{+}$ & $\mathrm{Mg}^{2+}$ & $\mathrm{Ca}^{2+}$ & $\mathrm{Cl}^{-}$ & $\mathrm{HCO}_{3}^{-}$ & $\mathrm{HPO}_{4}{ }^{2-}$ & Others \\
\hline 1 & $A$ & 142.0 & 5.0 & 1.5 & 2.5 & 148.8 & 4.2 & 1.0 & - \\
\hline 2 & $B$ & 137.8 & -- & - & - & 137.8 & - & - & - \\
\hline 3 & $C$ & 142.0 & 5.0 & 1.5 & - & 143.8 & 4.2 & 1.0 & - \\
\hline 4 & $D$ & 142.0 & 5.0 & - & 2.5 & 145.8 & 4.2 & 1.0 & - \\
\hline 5 & $E$ & 142.0 & - & 1.5 & 2.5 & 145.8 & 4.2 & - & - \\
\hline 6 & $F$ & 137.8 & 5.0 & 1.5 & 2.5 & 148.8 & - & 1.0 & - \\
\hline 7 & G & 142.0 & 3.0 & 1.5 & 2.5 & 148.8 & 4.2 & - & - \\
\hline 8 & $H$ & 142.0 & 5.0 & 1.5 & 2.5 & 148.8 & 4.2 & 1.0 & F $3.2 \mathrm{mg}$ \\
\hline 9 & $I$ & 142.0 & 5.0 & 1.5 & 2.5 & 148.8 & 4.2 & 1.0 & Albumin $1 \mathrm{~g}$ \\
\hline 10 & $J$ & 142.0 & 5.0 & 1.5 & 2.5 & 148.8 & 4.2 & 1.0 & Collagen $4.2 \mathrm{mg}$ \\
\hline 11 & $K$ & 142.0 & 5.0 & 1.5 & 2.5 & 148.8 & 4.2 & 1.0 & ALPase $10 \mathrm{mg}$ \\
\hline
\end{tabular}

ion ; and solution $G$, no $\mathrm{HPO}_{4}{ }^{2-}$ ion. Solution $H$ is an SBF-containing $\mathrm{F}^{-}$. Solutions $I, J$, and $K$ are the SBF containing proteins; egg albumin*, bovine collagen (type 1)**, and alkaline phosphatase (calf intestine)\#. The vials containing the OCP specimens and the test solutions were incubated at $37^{\circ} \mathrm{C}$ in a water bath. To investigate the effect of $\mathrm{pH}$ of the solution, pH 5.8 and 8.2 of solution $A$, namely SBF, were also prepared by adjusting the amounts of $\mathrm{HCl}$. Furthermore, the solution $A$ was incubated at 5 and $62^{\circ} \mathrm{C}$ in a water bath to investigate the effect of temperature.

After soaking in these conditions, the specimens were filtered, rinsed with distilled water, and dried at $60^{\circ} \mathrm{C}$ for $8 \mathrm{~h}$. The dried specimens were characterized by $\mathrm{X}$-ray diffraction study\#, and infrared spectroscopy ${ }^{\circledR}$. Particle shapes were examined by using a field emission-type scanning electron microscope (SEM) ${ }^{\circledR}$.

\section{RESULTS}

Fig. 1 shows X-ray diffraction patterns of the lyophilized OCP powders after soaking in the 11 kinds of solutions at $37^{\circ} \mathrm{C}$. The OCP completely disappeared and only apatite could be observed after soaking in solutions $B$ and $D$, which contained no $\mathrm{Mg}^{2+}$, whereas OCP still remained after soaking in all other solutions. Fig. 2 shows X-ray diffraction patterns of the lyophilized OCP powders after soaking in $\mathrm{pH} 5.8,7.2$, and 8.2 of solution $A$ at $37^{\circ} \mathrm{C}$ (left) and in the solution $A$ at 5,37 , and $62^{\circ} \mathrm{C}$ (right). It was found that $\mathrm{X}$-ray intensities of the OCP crystal decreased at $\mathrm{pH} 8.2$ and at $62^{\circ} \mathrm{C}$. Similar X-ray diffraction results were obtained in the soaking tests of fresh OCP without drying, and both the powders dried at room temperature and at $60^{\circ} \mathrm{C}$.

* Egg albumin, Tokyo Kasei Kogyo Co., Tokyo, Japan

* * $99 \%$ formulated by $0.012 \mathrm{HCl}$, Collaborative Research Inc., Bedford, MA, USA

\# EIA grade specific activity approximately $3500 \mathrm{u} / \mathrm{mg}$, Zymed Laboratories Inc., San Francisco, CA, USA.

\# Rotaflex RAD-rC, Rigaku, Tokyo, Japan

@ IR-810, JASCO, Tokyo, Japan

@@ JSM-6400FX, JEOL, Tokyo, Japan 


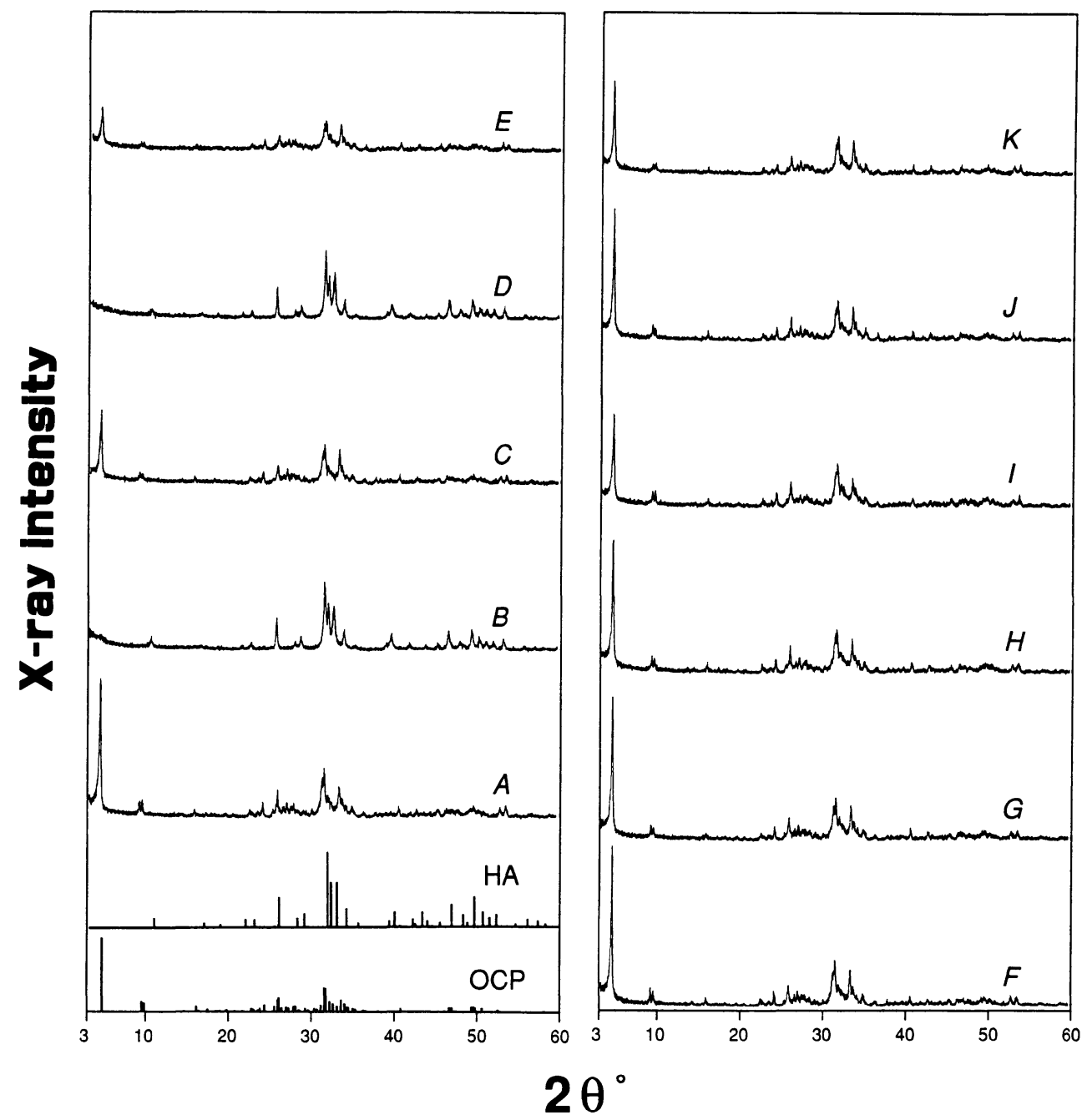

Fig. 1 X-ray diffraction patterns of the lyophilized OCP powder after soaking for 3 weeks in the 11 kinds of solutions at $37^{\circ} \mathrm{C}$.

The presence of OCP crystal can easily be detected by using the (010) line at $d=18.7 \AA$ $\left(2 \theta=4.7^{\circ}\right)$ (JCPDS 26-1056). The conversion (\%) of OCP to apatite was determined by using a calibration curve between the X-ray intensities of (010) line of OCP and the amounts of OCP in the mixtures of the lyophilized OCP powder and an apatite powder. This apatite had a composition of $\mathrm{Ca}_{3}\left(\mathrm{PO}_{4}\right)_{2}$ and a similar X-ray diffraction pattern to that of the apatite transformed from OCP. Fig. 3 shows the conversion of the four kinds of OCP (the precipitate without drying and the powders dried in three conditions) after soaking in 11 kinds of solutions. The conversion of OCP in both the solutions $B$ and $D$ were $50-100 \%$ and were higher than those in other solutions (5-30\%). Fig. 4 shows the conversion of the four kinds of OCP after soaking in solution $A$ at $\mathrm{pH} 5.8,7.2$, and 8.2 at $37^{\circ} \mathrm{C}$ (left) and at 5,37 , and $62^{\circ} \mathrm{C}$ 
(right). It was found that the conversion of $\mathrm{OCP}$ in $\mathrm{pH} 8.2$ and at $62^{\circ} \mathrm{C}$ was higher than any other conditions.

Two-way analysis of variance (ANOVA) was performed on the conversion of OCP. ANOVA for each dry condition, kind of solution, $\mathrm{pH}$, and temperature are given in Tables

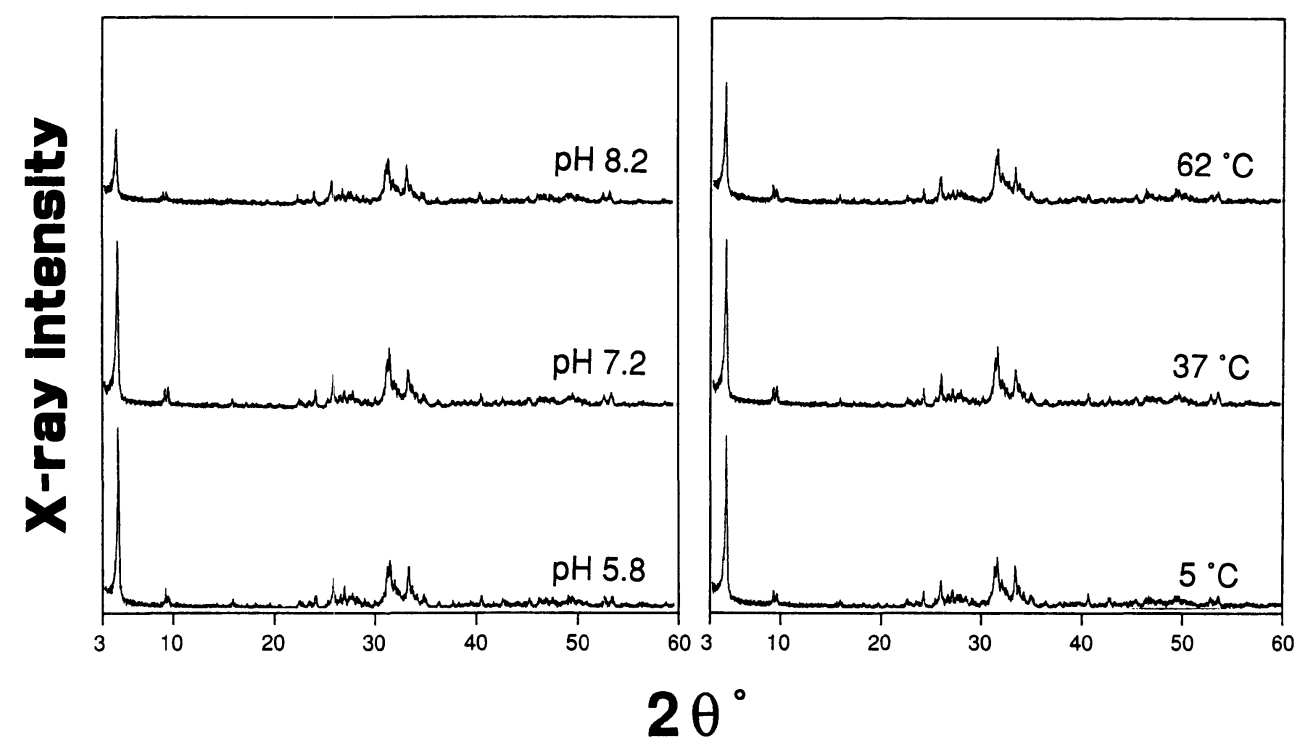

Fig. 2 X-ray diffraction patterns of the lyophilized OCP powder after soaking for 3 weeks at $\mathrm{pH}$ $5.8,7.2$, and 8.2 in solution $A$ at $37^{\circ} \mathrm{C}$ (left) and in solution $A$ at $5^{\circ} \mathrm{C}, 37^{\circ} \mathrm{C}$, and $62^{\circ} \mathrm{C}$ (right).

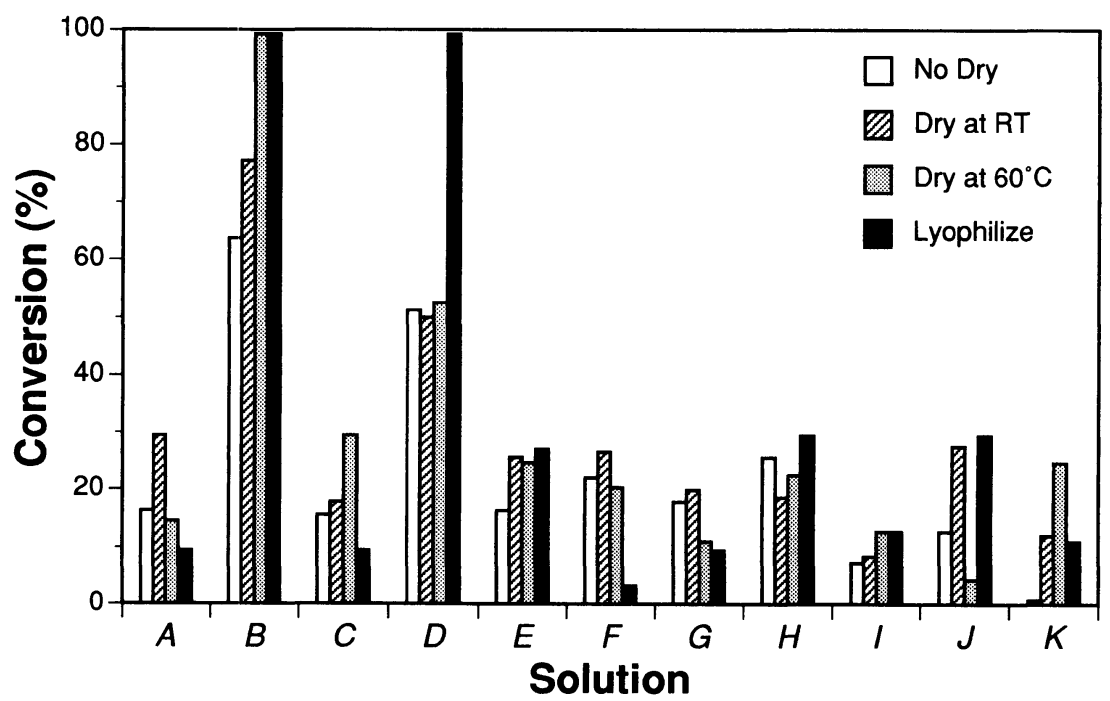

Fig. 3 Conversion of the fresh OCP precipitate without drying and the OCP powders dried in three conditions after soaking for 3 weeks in the 11 kinds of solutions at $37^{\circ} \mathrm{C}$. 
2, 3 and 4. In each ANOVA, the kind of solution, $\mathrm{pH}$, and temperature significantly influenced the conversion of OCP $(p<0.01)$. The kind of solution, in particular, had the largest contribution at $83.9 \%$. However, no significant difference between the dry conditions was observed in each ANOVA $(p>0.05)$.

Fig. 5 shows infrared spectra of the lyophilized OCP powder after soaking in the 11 kinds of solutions at $37^{\circ} \mathrm{C}$. Several $\mathrm{PO}_{4}$ bands ${ }^{22)}$, characterized by $\mathrm{OCP}$ around $1000-1200 \mathrm{~cm}^{-1}$,
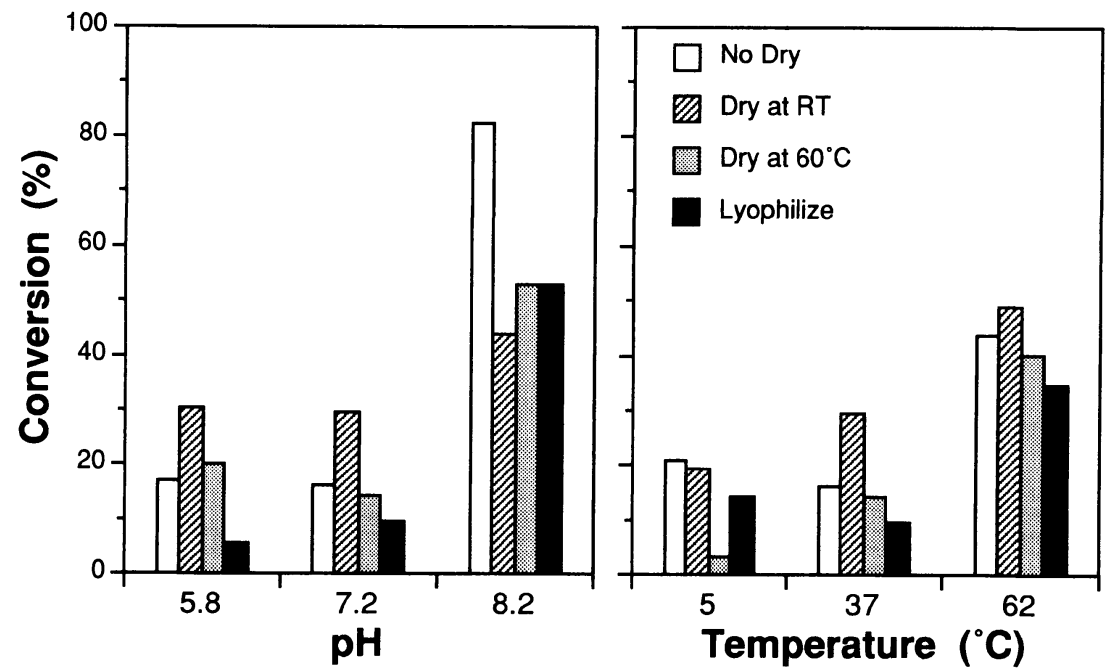

Fig. 4 Conversion of the fresh OCP precipitate without drying and the OCP powders dried in three conditions after soaking for 3 weeks at $\mathrm{pH} 5.8,7.2$, and 8.2 in solution $A$ at $37^{\circ} \mathrm{C}$ (left) and in solution $A$ at $5^{\circ} \mathrm{C}, 37^{\circ} \mathrm{C}$, and $62^{\circ} \mathrm{C}$ (right).

Table 2 Two-way analysis of variance for conversion (\%) of the fresh OCP precipitate without drying and the OCP powders dried in three conditions after soaking for 3 weeks in 11 kinds of solutions

\begin{tabular}{cccccc}
\hline Source & d. f. & Sum of squares & Mean square & Fvalue & Contribution \\
\hline Solution & 10 & 22649.8 & 2265.0 & $17.26^{* *}$ & 83.9 \\
Dry Condition & 3 & 411.8 & 137.3 & 1.05 & 1.5 \\
Error & 30 & 3937.7 & 131.3 & & 14.6 \\
\hline Total & 43 & 26999.3 & & & 100.0
\end{tabular}

Table 3 Two-way analysis of variance for conversion (\%) of the fresh OCP precipitate without drying and the OCP powders dried in three conditions after soaking for 3 weeks at $\mathrm{pH}$ 5.8, 7.2, and 8.2 in solution $A$

\begin{tabular}{crcccr}
\hline Source & d. f. & Sum of squares & Mean square & Fvalue & Contribution \\
\hline pH & 2 & 4246.3 & 2123.2 & $13.47 * *$ & 75.5 \\
Dry Condition & 3 & 432.2 & 144.1 & 0.91 & 7.7 \\
Error & 6 & 945.7 & 157.6 & & 16.8 \\
\hline Total & 11 & 5624.1 & & & 100.0
\end{tabular}


changed to a single band around $1030 \mathrm{~cm}^{-1}$ with a small shoulder around $1150 \mathrm{~cm}^{-1}$, and $\mathrm{HPO}_{4}{ }^{2-}$ bands at 869 and $910 \mathrm{~cm}^{-1}$ changed to $865 \mathrm{~cm}^{-1}$ after soaking in both solutions $B$ and $D$, whereas the spectra little changed in other solutions. Furthermore, the $\mathrm{CO}_{3}$ band ${ }^{23,24)}$ around $1430 \mathrm{~cm}^{-1}$ was also observed in the spectra after soaking in solutions $B$ and $D$.

Table 4 Two-way analysis of variance for conversion (\%) of the fresh OCP precipitate without drying and the OCP powders dried in three conditions after soaking for 3 weeks in solution $A$ at $5^{\circ} \mathrm{C}, 37^{\circ} \mathrm{C}$, and $62^{\circ} \mathrm{C}$

\begin{tabular}{crcccc}
\hline Source & d. f. & Sum of squares & Mean square & Fvalue & Contribution \\
\hline Temperature & 2 & 1796.6 & 898.3 & $36.13^{* *}$ & 77.6 \\
Dry Condition & 3 & 368.1 & 122.7 & 4.97 & 15.9 \\
Error & 6 & 149.2 & 24.9 & & 6.5 \\
\hline Total & 11 & 2313.9 & & & 100.0
\end{tabular}

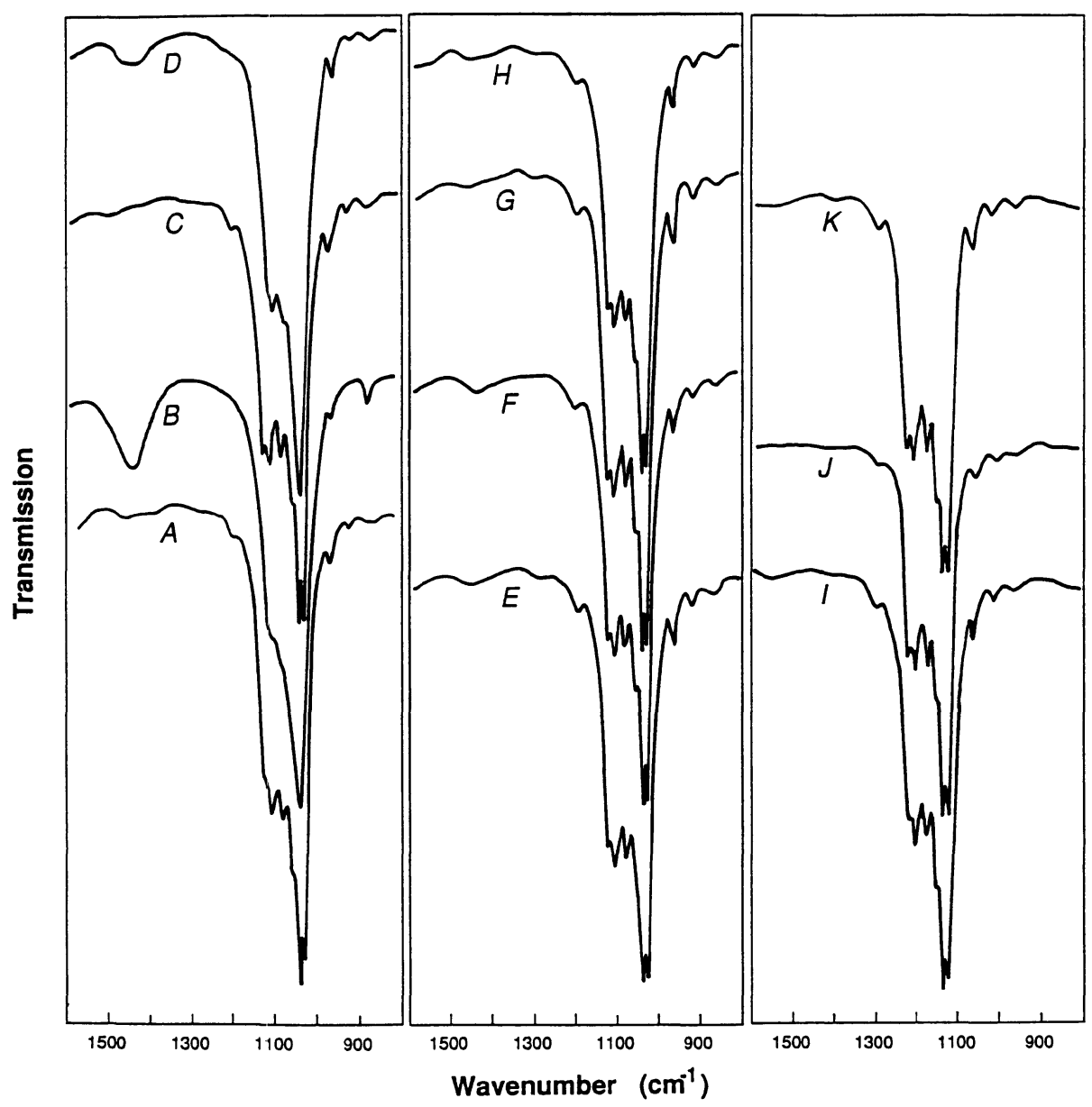

Fig. 5 Infrared spectra of the lyophilized OCP powder after soaking for 3 weeks in the 11 kinds of solutions at $37^{\circ} \mathrm{C}$. 
Although solution $B$ contained no carbonate, it seems that atmospheric $\mathrm{CO}_{2}$ gas dissolved in the solution and $\mathrm{HCO}_{3}{ }^{-}$ions might be incorporated in the apatite transformed from OCP. Fig. 6 shows the IR spectra of the lyophilized OCP after soaking in solution $A$ at pH 5.8, 7.2 , and 8.2 at $37^{\circ} \mathrm{C}$ (left) and at 5,37 , and $62^{\circ} \mathrm{C}$ (right). The $\mathrm{PO}_{4}$ bands slightly changed at pH 8.2 and $62^{\circ} \mathrm{C}$. Similar results for IR study were obtained in the soaking tests of fresh OCP without drying and of the powders dried at room temperature and at $60^{\circ} \mathrm{C}$. In consideration of the X-ray diffraction study, it is suggested that in the solutions without $\mathrm{Mg}^{2+}$, most of the OCP transformed to carbonate calcium-deficient apatite ${ }^{25)}$ and incorporated $\mathrm{HPO}_{4}{ }^{2-}$ with low crystallinity such as biological apatite.

Fig. 7 shows SEM micrographs of the lyophilized OCP powder after soaking in solutions $A, B, C$, and $D$. It was found that OCP crystals changed little after soaking in both solutions $A$ and $C$, whereas needle-like crystals could be seen in both the solutions $B$ and $D$. The morphological changes of OCP in other solutions were slight as in solutions $A$ and $C$. From the results of $\mathrm{X}$-ray diffraction and IR study, it seems that the needle-like crystals are the carbonate apatite with low crystallinity.

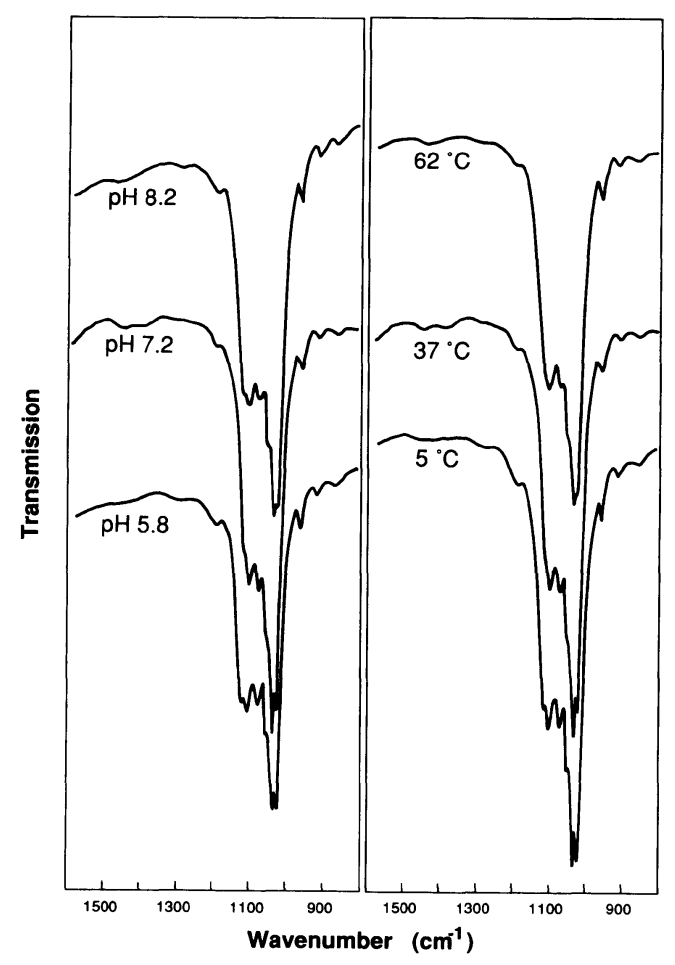

Fig. 6 Infrared spectra of the lyophilized OCP powder after soaking for 3 weeks at $\mathrm{pH}$ $5.8,7.2$, and 8.2 of solution $A$ at $37^{\circ} \mathrm{C}$ (left) and in solution $A$ at $5{ }^{\circ} \mathrm{C}, 37^{\circ} \mathrm{C}$, and $62^{\circ} \mathrm{C}$ (right). 

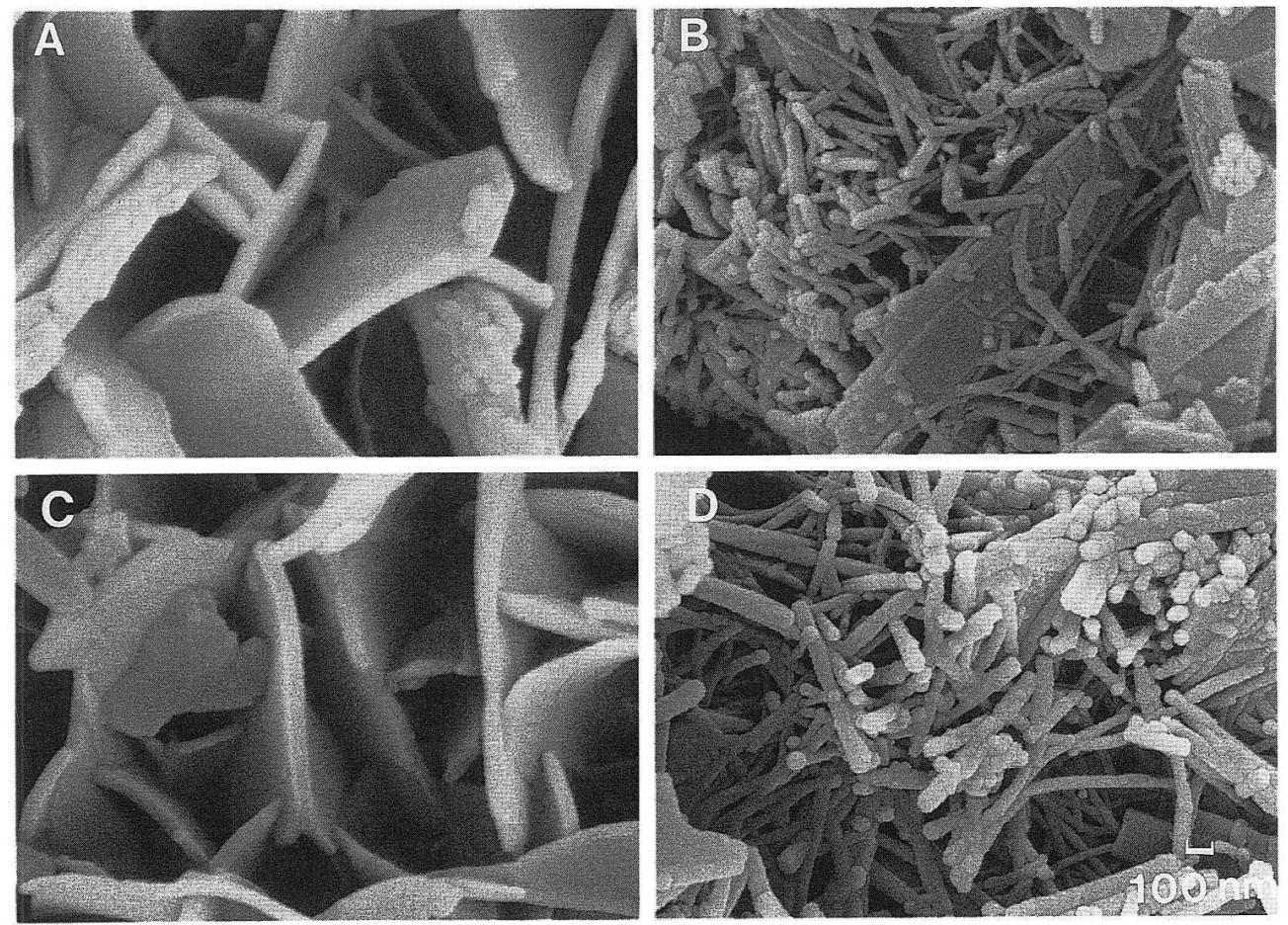

Fig. 7 SEM micrographs of the lyophilized OCP powder after soaking for 3 weeks in solutions $A$, $B, C$, and $D$ at $37^{\circ} \mathrm{C}$.

\section{DISCUSSION}

In the present study, it was concluded that $\mathrm{Mg}^{2+}$ ions were the most effective inhibitor of the transformation of OCP to apatite in vitro, and the presence of other ions and proteins were not statistically significant. It is known that the presence of $\mathrm{Mg}^{2+}$ ions cause some reduction in the crystallization of $\mathrm{OCP}^{3}$. In the aqueous system, $\mathrm{Mg}^{2+}$ ions are substituted into the $\mathrm{Ca}^{2+}$ sites, although $\mathrm{Mg}^{2+}$ ions do not enter solid phases to any great extent. $\mathrm{Mg}^{2+}$ ions induce a clear contraction along the $\mathrm{c}$-axis dimension of apatite, because $\mathrm{Mg}^{2+}$ ions have a small radius of $0.65 \AA$, as opposed to the $0.99 \AA$ of $\mathrm{Ca}^{2+}$ ions $^{26)}$. In contrast, most apatite in which some anions have been substituted show contraction along the a-axis; e.g., $\mathrm{CO}_{3}{ }^{2-}$ ions substitute $\mathrm{PO}_{4}{ }^{3-}$ sites of apatite and $\mathrm{F}^{-}$ions substitute $\mathrm{OH}^{-}$sites. These metal ions have also smaller ionic radii than the $\mathrm{PO}_{4}{ }^{3-}$ and $\mathrm{OH}^{-}$. Biological apatite generally grows along $\mathrm{c}$-axis in biological systems. Therefore, it seems that $\mathrm{Mg}^{2+}$ ions can most strongly affect the crystallization of calcium phosphates, since $\mathrm{Mg}^{2+}$ ions have a grcater influence on the lattice arrangement along the c-axis than do other ions. One of the effects of the low crystallinity by $\mathrm{Mg}^{2+}$ ions may be surface poisoning ${ }^{27)}$. $\mathrm{Mg}$ (or some of its complexes) can poison the surface of apatite nuclei by being absorbed into the active growth sites, so that growth either stops or proceeds at a rate so slow that other phases can nucleate. This process most likely depends on the $\mathrm{Mg}$ concentration in solution and on the surface structure of crystal faces. 
Apatite obtained by the transformation from OCP in this study was not stoichiometric apatite $(\mathrm{Ca} / \mathrm{P}=1.67)$, but $\mathrm{Ca}$-deficient apatites such as biological apatite. Brown et al. $\left.{ }^{6}\right)$ proposed that the transformation of OCP to apatite in biological systems can proceed either by in situ hydrolysis or by dissolution of OCP and precipitation of apatite incorporating ions present in the micro-environment, or both. Recently, LeGeros et al. ${ }^{13)}$ concluded that its transformation occurred by the process of dissolution of OCP and subsequent precipitation of Ca-deficient apatites, incorporating $\mathrm{CO}_{3}{ }^{2-}, \mathrm{HPO}_{4}{ }^{2-}$, or $\mathrm{F}^{-}$present in solution. We also concluded that the transformation of OCP to apatite is predominantly determined by the dissolution of OCP and the precipitation of apatite on the surface of the OCP, and that the incorporation of $\mathrm{Mg}^{2+}$ interferes with the precipitation process because of surface poisoning.

The results in this study are consistent with the hypothesis that both higher $\mathrm{pH}$ and higher temperature of the solution significantly promoted the transformation of OCP to apatite, and this promotion may be due to the chemical and thermodynamic equilibrium ${ }^{28,29)}$, because of the involvement of dissolution and precipitation.

Furthermore, OCP obtained in different drying conditions showed nearly the same behavior in the transformation. When drying living tissue, lyophilized specimens generally show a relatively large specific surface area. However, the lyophilized OCP powder in the present study showed nearly the same morphology with those of powders dried at room temperature and at $60^{\circ} \mathrm{C}$. Then, it seems that the similarity in morphology may cause similar chemical behavior, such as dissolution and precipitation in the solution, although each OCP absorbed a different amount of water. This may explain why the drying conditions did not significantly affect the transformation of OCP to apatite.

In comparison with the results in vivo in our previous report ${ }^{12)}$, it seems that physiological reactions have a great effect on the transformation of OCP to apatite in vivo. Although the body fluid around the implanted OCP contains $\mathrm{Mg}^{2+}$ ions, the physiological environment seems to negate their influence and promote transformation. The physiological reaction is not simple inorganic or organic chemical reaction, since major proteins contained in the body fluid showed no significant effect in vitro in this study. Furthermore, implantation of biomaterials always involves the formation of a surgical wound. Consequently, the initial interfacial reaction can involve the interaction of the implanted material surfaces with serum components present at the wound site. For instance, the normal $\mathrm{pH}$ of the body fluid is about neutral, in the range of 7.2 to 7.4. At injured sites, the $\mathrm{pH}$ shifts to acidic values of about 5.2. In hematoma, it can drop to 4.0. In case of infection, the $\mathrm{pH}$ becomes alkaline. ${ }^{30}$ Furthermore, the temperature around the implant rises due to some physiological reactions

related to fever. The physiological reaction around the implant changes as the surgical wound heals and as the test animal grows. Therefore, it appears that the difference between the transformation behavior of OCP to apatite in vivo and in vitro is due to unknown factors in the highly complex in vivo environment.

\section{CONCLUSION}

Solutions without $\mathrm{Mg}^{2+}$, high $\mathrm{pH}$, and high temperature significantly promoted the transformation of OCP to apatite, although its transformation was not significantly influenced by the 
drying conditions. Especially, the presence of $\mathrm{Mg}^{2+}$ in the solution had the greatest influence on transformation. The effect of the presence of other ions and some proteins were not statistically significant. These results suggest that the transformation of OCP to apatite in vitro is mainly determined by the dissolution of OCP and the precipitation of apatite, and the incorporation of $\mathrm{Mg}^{2+}$ interrupts the precipitation process because of surface poisoning.

\section{ACKNOWLEDGMENT}

This research was supported by a Grant-in-Aid for General Scientific Research (No. 05671645) from the Ministry of Education, Science and Culture of Japan.

\section{REFERENCES}

1) Koutsoukos, P. G. and Nancollas, G. H. : The kinetics of mineralization of human dentin in vitro, $J$ Dent Res 60 : 1922-1928, 1981.

2) Kani, T., Kani, M., Moriwaki, Y. and Doi, Y.: Microbeam X-ray diffraction analysis of dental calculus, J Dent Res 62: 92-95, 1983.

3) LeGeros, R. Z., Kijkowska, R. and LeGeros, J. P. : Formation and transformation of octacalcium phosphate, OCP : A preliminary report, Scanning Electron Microscopy IV : 1771-1777, 1984.

4) Eidelman, N., Chow, L. C. and Brown, W. E. : Calcium phosphate phase transformations in serum, Calcif Tissue Int 41: 18-26, 1987.

5) Monma, H.: Octacalcium phosphate, Gypsum \& Lime 166 : 33-41, 1980. (in Japanese)

6) Brown, W. E., Smith, J. P., Lehr, J. R. and Frazier, A. W.: Crystallographic and chemical relations between octacalcium phosphate and hydroxyapatite, Nature 196 : 1048-55, 1962.

7) Cheng, P-T.: Octacalcium phosphate formation in vitro: Implications for bone formation, Calcif Tissue Int 37: 91-94, 1985.

8) Siew, C., Gruninger, S. E., Chow, L. C. and Brown, W. E. : Procedure for the study of acidic calcium phosphate precursor phases in enamel mineral formation, Calcif Tissue Inst 50 : 144-148, 1992.

9) Posner, A. S. and Betts, F. : Synthetic amorphous calcium phosphates and its relation to bone mineral structure, Acc Chem Res 8: 273-281, 1975.

10) Sauer, G. R., and Wuthier, R. E. : Fourier transform infrared characterization of mineral phases formed during induction of mineralization by collagenase-released matrix vesicles in vitro, $J$ Biol Chem 263 (27) : 13718-13724, 1988.

11) Ban, S.: Synthesis of octacalcium phosphate by reactions of dicalcium phosphate dihydrate and calcium carbonate, Phosphorus Research Bulletin 1 (1) : 155-160, 1991.

12) Ban, S., Jinde, T., and Hasegawa, J.: Phase transformation of OCP in vivo and in vitro, Dent Mater $J$ 11 : 130-140, 1992.

13) LeGeros, R. Z., Daculsi, G., Orly, I., Abergas, T. and Torres, W. : Solution-mediated transformation of octacalcium-phosphate (OCP) to apatite, Scanning Microscopy 3 (1) : 129-138,1989.

14) Boulet, M., Marier, J. R. and Rose, D. : Effect of magnesium on formation of calcium phosphate precipitates, Arch Biochem Biophys 96 : 629-636, 1962.

15) Bachara, B. N., Trautz, O. R. and Simon, S. L. : Precipitation of calcium carbonates and phosphates. III. The effects of magnesium and fluoride ions on the spontaneous precipitation of calcium carbonates and phosphates, Arch Biochem Biophys 106 : 731-738, 1965.

16) Rowles, S. L.: The precipitation of whitlockite from aqueous solutions, Bull Soc Chim Fr 1797-1802, 1968.

17) Tung, M. S., Chickerur, N. S. and Brown, W. E. : Studies on the hydrolysis of octacalcium phosphate, $J$ Dent Res (Special Issue A) 58: 369, Abst. No. 1112, 1979.

18) Wuthier, R. E. and Eanes, E. D. : Effect of phospholipids on the transformation of amorphous calcium phosphate to hydroxyapatite in vitro, Calcif Tiss Res 19: 197-210, 1975. 
19) Blumenthal, N. C., Cosma, V. and Gomes, E. : Regulation of hydroxyapatite formation by gelatin and type I collagen gels, Calcif Tissue Int 48: 440-442, 1991.

20) Doi, Y., Horiguchi, T., Kim, S-H., Moriwaki, Y., Wakamatsu, N., Adachi, M., Shigeta, H., Sasaki, S. and Shimokawa, H. : Immobilized DPP and other proteins modify OCP formation, Calcif Tissue Int 52: 139-145, 1993.

21) Kokubo, T., Hayashi, T., Sakka, S., Kitsugi, T. and Yamamuro, T.: Bonding between bioactive glasses, glass-ceramics or ceramics in a simulated body fluid, Yogyo-Kyokai-Shi 95: 785-791, 1987.

22) Fowler, B. O., Moreno, E. C. and Brown, W. E. : Infra-red spectra of hydroxyapatite, octacalcium phosphate and pyrolysed octacalcium phosphate, Arch Oral Biol 11 : 477-492, 1966.

23) Elliott, J. C., Holcomb, D. W. and Young, R. A. : Infrared determination of the degree of substitution of hydroxyl by carbonate ions in human dental enamel, Calcif Tissue Int 37 : 372-375, 1985.

24) Rey, C., Renugopalakrishnan, V., Collins, B. and Glimcher, M. J. : Fourier transform infrared spectroscopic study of the carbonate ions in bone mineral during aging, Calcif Tissue Int 49: 251-258, 1991.

25) Daculsi, G., LeGeros, R. Z., Heughebaert, M. and Barbienx, I. : Formation of carbonate apatite crystals after implantation of calcium phosphate ceramics, Calcif Tissue Int 46 : 20-27, 1990.

26) Okazaki, M., Takahashi, J. and Kimura, H.: Unstable behavior of magnesium-containing hydroxyapatite, Caries Res 20 : 324-331, 1986.

27) Abbona, F. and Franchini-angela, M.: Crystallization of calcium and magnesium phosphates from solutions of low concentration, J Cryst Growth 104 : 661-671, 1990.

28) Meyer, J. L. and Eanes, E. D. : A thermodynamic analysis of the amorphous to crystalline calcium phosphate transformation, Calcif Tiss Res 25: 59-68, 1978.

29) Kibalczyc, W., Christoffersen, J., Christoffersen, M. R., Zielenkiewicz, A. and Zielenkiewicz, W.: The effect of magnesium ions on the precipitation of calcium phosphates, J Cryst Growth 106: 355-366, 1990.

30) Pohler, O. E. M. : Failure of metallic orthopedic implants, Metal Handbook 9 th ed. vol. 11, ASM International, Metals Park, Ohio, 1986, pp. 670-694. 


\title{
本号掲載論文の和文抄録
}

\author{
新しいデンチンボンディング材の引張接着強さとギャップ形成について \\ M. F. BURROW, 林田桃子, 根岸 正, 二階堂徹 \\ 田上順次, 高津寿夫, 細田裕康 \\ 東京医科歯科大学歯学部歯科保存学第一講座
}

新しいデンチンボンディング材を用いて, 象牙質の前 処理, プライミング処理の影響について, 引張試験, ギ ヤップテストを行って検討した. 引張試験の結果, 前処 理およびプライマー処理の有無によって接着強さに有意 な差が認められ,リン酸による前処理と HEMA, グルタ ルアルデヒドを含むプライマーの組み合わせで 151.3 $\mathrm{kgf} / \mathrm{cm}^{2}$ と最も高い接着強さが得られた。一方, ギャップ テストの結果, すべての群においてギャップの形成が認
められたが, その様相は様々であり, ばらつきが大きか つた. また, 引張接着強さとギャップ形成との間には, 統計学的な相関は認められなかった，以上より，新しい ボンディング材はどの群においてもほぽ良好な接着強さ を示すと思われるが, 酸処理およびプライマー処理の併 用によって最も高い接着強さが得られ，ギャップを最小 にできることがわかった.

実験室的にリン酸八カルシウムのアパタイトへの転化に影響を与える因子

伴 清治, 松浦 満, 有本憲弘, 林崎順子, 伊藤泰明

長谷川二郎

愛知学院大学歯学部歯科理工学講座

調製したままの乾燥前のリン酸八カルシウム $(\mathrm{OCP})$ 沈殿物と乾燥条件の異なる 3 種の $\mathrm{OCP}$ 粉末を 3 週間, 11 種の生理的溶液に浸漬した. この溶液は $\mathrm{Ca}^{2+}, \mathrm{Mg}^{2+}$, $\mathrm{K}^{+}, \mathrm{Na}^{+}, \mathrm{HCO}_{3}{ }^{-}, \mathrm{HPO}_{4}{ }^{2-}, \mathrm{F}^{-}$, アルブミン, コラー ゲン,アルカリフォスファターゼより構成されている. また, ある溶液で $\mathrm{pH}$ を 3 つに変えた場合, 温度を 3 段階 に変えた場合についても浸漬実験をした，X線回折の測 定結果より, OCP は $\mathrm{Mg}^{2+}$ を含まない溶液への浸漬後は 結晶性の低いアパタイトにほとんど転化していた。その $\mathrm{X}$ 線回折の強度変化より求めた $\mathrm{OCP}$ の転化量について
行った分散分析結果より, OCP のアパタイトへの転化は 溶液の種類， $\mathrm{pH}$, 温度に対して有意差があり (危険率 1 \%以下),一方乾燥条件についての有意差は認められなか つた(危険率 $5 \%$ 以上). また, 赤外分光分析スペクトル より, $\mathrm{Mg}^{2+}$ を含まない溶液中で $\mathrm{OCP}$ から転化するアパ タイトは $\mathrm{CO}_{3}$ が含まれているが, $\mathrm{Mg}^{2+}$ を含む溶液中では ほとんど変化がなかった.これらの結果は溶液中での $\mathrm{Mg}^{2+}$ の存在が OCP からアパタイトへの転化に対し, 最 も効果的な因子であると考えられた。 